\title{
A MAGYAR ETNIKAI TÉRSZERKEZET VÁLTOZÁSAI A HONFOGLALÁSTÓL NAPJAINKIG
}

\author{
(Changing face of the Hungarian ethnic territory from the Hungarian \\ conquest till today)
}

KOCSIS KÁROLY

Európa nemzetei közőtt alig van olyan, melynek lélekszáma, etnikai területe oly feltünő mértékben változott volna az elmúlt évezredben, mint a magyaroké. A településterület dinamikáját, többszöri szétterjedését-összezsugorodását tekintve talán csak a - XV-XVII. században szintén a keresztény-muzulmán frontvonal övezetében szétmorzsolódott horvátok és a német-orosz ütkőzőzónában őrlődött lengyelek esete hasonlítható hozzájuk. A magyar etnikai térszerkezet rapszodikus változásai végső soron hazánknak, a Kárpátmedencének a földrajzi fekvésével függtek össze, mely a nyugati, a keleti keresztény és az iszlám világ (XV-XIX. sz.) találkozási pontjában, a német és a szláv etnikai tömbök ölelkezésében alapvető hatást gyakorolt a történelmi eseményekre - természeti földrajzi adottságai révén -, a magyarság életmódjával összefüggésben pedig a kỏzépkor folyamán meghatározta őseink településterületének a nagyságát és növeke-désének korlátait is.

\section{Vereckétől Mohácsig (896-1526)}

A kb. 150-400 ezer főnyi honfoglaló magyarság a X. század végén érkezett a politikailag akkor még alig szervezett, többnyire gyér, kb. 200 ezres szláv (szlavón, szlovén-karantán, morva, fehér horvát, bolgár stb.) - avar népességü új hazájába, a Kárpátmedencébe (Györffy Gy. 1995, Kovacsics J. 1995, Kristó Gy. 1995). Őseink a XI. század során akkori félnomád életmódjuknak leginkább megfelelö, korábbi hazájuk természeti környezetére emlékeztető erdős (fỏként tölgyes) sztyeppen, stratégiai fekvésü folyóvölgyekben és alacsony dombvidéki területeken települtek le. Az általában legeltetésre alkalmatlan, gyér aljnövényzetü bükkösök határáig terjedő korai magyar településterületet többnyire az évi $600 \mathrm{~mm}$-nél kevesebb csapadék és a lösz nagyobb mennyiségü elófordulása jellemezte (Kniezsa I. 1938, Mendöl T. 1947). A X. században a magyarok legnagyobb sürúségben - a hadászatilag fontos gyepủkapukon kívül - a 900 nyarán elfoglalt Dunántúlt, azon belül is az Óbuda-Csepel-Fehérvár-Pécs közötti fejedelmi szállásterület övezetét lakták. Ez fóként - a stratégiai szempontok mellett - a honfoglalók félnomád életmódjának leginkább megfelelö változatos és eléggé tagolt domborzatnak volt köszönhető (vö. Mendöl T. 1947). Ugyanakkor etnikai területük az alföldi árterekre, a homokvidékekre és a hegy-, valamint a dombvidéki zártabb erdőségekre többnyire nem terjedt ki. A nyugati magyar kalandozó csapatok augsburgi vereségét (955), a gyepüvédelmi rendszer megerősítését követően a XI. század végére a magyar etnikai terület kiterjedése a következó volt: északon a Pozsony - Galgóc - Garamszentbenedek Ipoly-medence - a gömöri Pelsőc - a Sáros megyei Eperjes-Sóvár - Töketerebes - Ungvár

Beregszász vonal; keleten az Erdélyi-medencét (föként a Mezőséget, a Küküllök 
vidékét, a Maros középsö szakaszának környékét) és a Nagy Alföldet kitöltve a hegyvidék lába; délen hozzávetöleg a Mura - Dráva - Duna vonala annyi eltéréssel, hogy a Szerémség északi fele és a Vuka vidéke magyar többségünek számított; nyugaton a Fertö Sopron - Kőszeg - Pinkamellék vonala (Kniezsa I. 1938, 1939) (1. ábra).

A török eredetü, de korán elmagyarosodott és gyepüőrző feladattal megbízott etnikumok közül a besenyöket föleg Moson, Sopron és Fejér megyékben, a székelyeket pedig a nyugat-dunántúli, morvamelléki és dél-erdélyi határvidéken telepítették le. Ez utóbbiak a XIII. század elejétỏl átköltöztek a jelenlegi Székelyföldre, átadva helyüket az egyre nagyobb számban Dél-Erdélybe telepített "szászoknak". A magyar etnikai területnek a korábbi gyepủzónába való hasonló benyomulása volt megfigyelhető ez időszakban föként a Sajó, Hernád és a Felső-Tisza mellékén. Ugyanakkor az etnikai tömbjüktől távol fekvö, morva-, vág-, poprádmelléki magyar határőrfalvak beolvadása is felgyorsult. A magyar településterület etnikai jellege a XV. századra a szlávok, besenyök - a tatárjárás után betelepített, fegyveres szolgálataik fejében területi autonómiát élvezö -, kunok és jászok többségének nyelvi asszimilációja révén meglehetősen homogénné vált. Ezzel a nagyfokú gyarapodással a tatárjárást követően erősen megritkult magyarság a XV-XVI. század fordulójára az ország kb. 4 milliós lakosságán belül elérte a $80 \%$-ot (Mályusz E. é. n., Szabó I. 1941). Ebben az idöpontban a 3,2 milliós magyarság lélekszáma messze meghaladta Anglia és Wales akkori 2 milliós össznépességét. A magyar nyelvhatár a mai Szlovákia, Kárpátalja területén a jelenleginél átlagosan 20-30 km-rel északabbra húzódott, sőt a távoli északon a magyar etnikai terulethez kanyaritotta Sáros megye középső területeit, Eperjes környékét is (Kniezsa I. 1939, 1941). Erdélyben a Székelyföld az akkor még túlnyomórészt magyar etnikumú Mezöségen, Szamos-, Kraszna-, Sebes-Körös- és Maros-völgyön keresztül összefüggő tömböt képezett az alföldi-partiumi magyar etnikai területtel (2. ábra). Délen pedig a Bánság sík- és dombvidéki része, a Bácska teljes egésze, a Szerémség északi fele, illetve Eszék - Valkóvár (ma Vukovár) vidéke túlnyomórészt magyar népességủ volt. Ezeken a XV. században még gazdaságilag virágzó, nagy népsủrủségủ délvidéki, szerémségi, bácsvidéki (bácskai), bánsági, temesközi (bánáti) területeken a határvidéki folytonos török portyázások, pusztitások, az 1514-es parasztháború és az azt követő megtorlások következményeként az itteni magyarság lélekszáma jelentősen lecsökkent, etnikai területének korábbi homogenitása - a folytonosan beköltözỏ szerb menekültek miatt - egyre inkább megszünt az 1520-as évèk elejére.

\section{Mohácstól Majtényig (1526-1711)}

A középkori magyar államiság bukásának jelképévé vált mohácsi csata és a Rákócziszabadságharc bukása (1711) közötti két évszázad során, mikor a Kărpảt-medence szinte teljes egésze csaknem állandó hadszíntérré vált, a $80 \%$-os magyar túlsúllyal jellemezhetó, középkor végi etnikai térszerkezet végérvényesen felbomlott. A törökellenes és belső háborúk során a magyarok száma 3,2 millióról 1,5-re csökkent, a nem-magyaroké viszont 1 millióról 1,7-re nőtt (Szabó I. 1941). A magyar lakosság a déli területekről, a Bánságból, Bácskából, Szerémségből és Szlavóniából szinte teljes egészében eltünt, de többségưk elpusztult illetve elmenekưlt az Erdélyi-medencéből, az Alföld középsö, a Dunántúl déli részeiről és a hódoltsági terület határán, az ún. végvárövezetből is. 


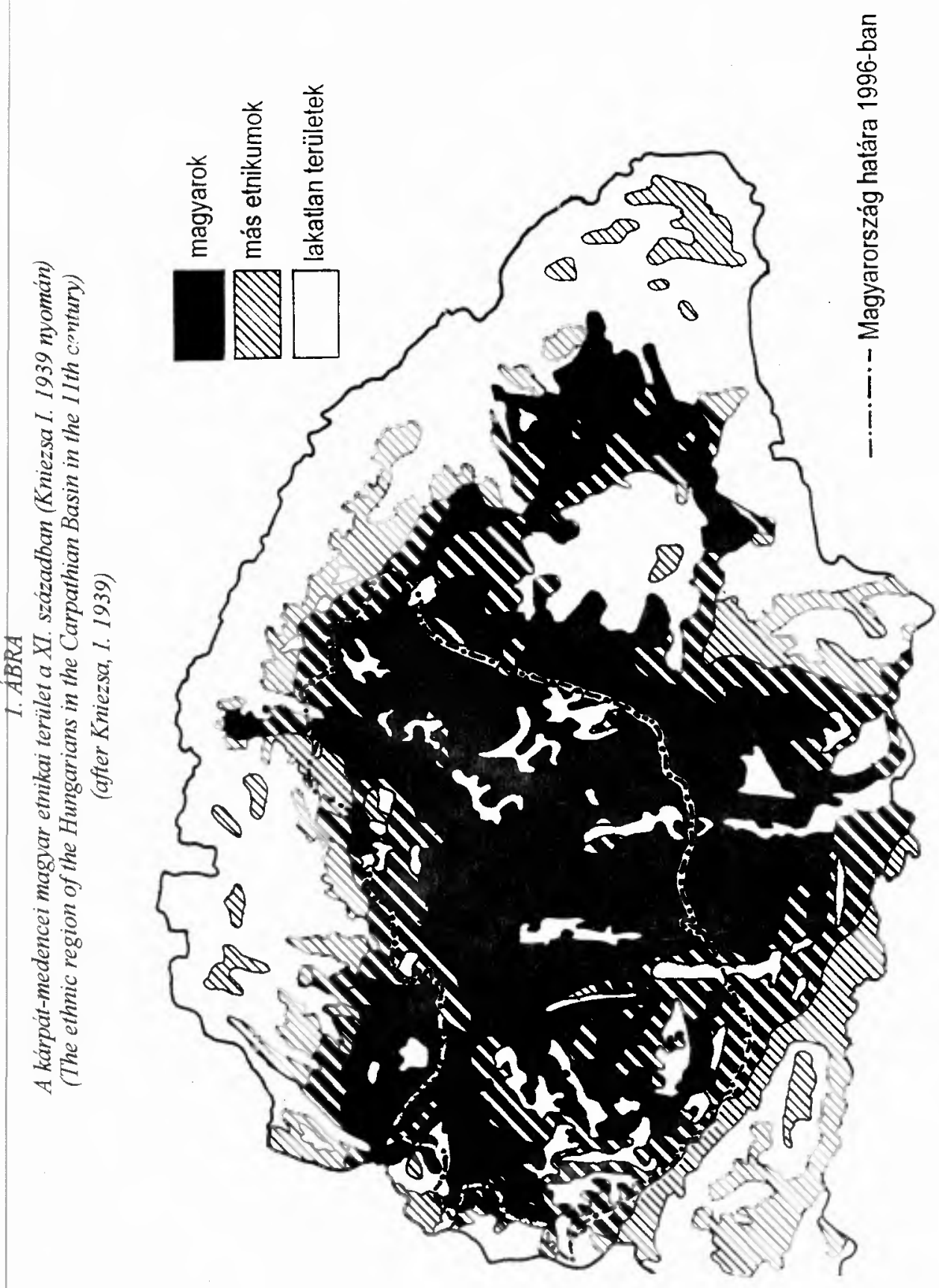




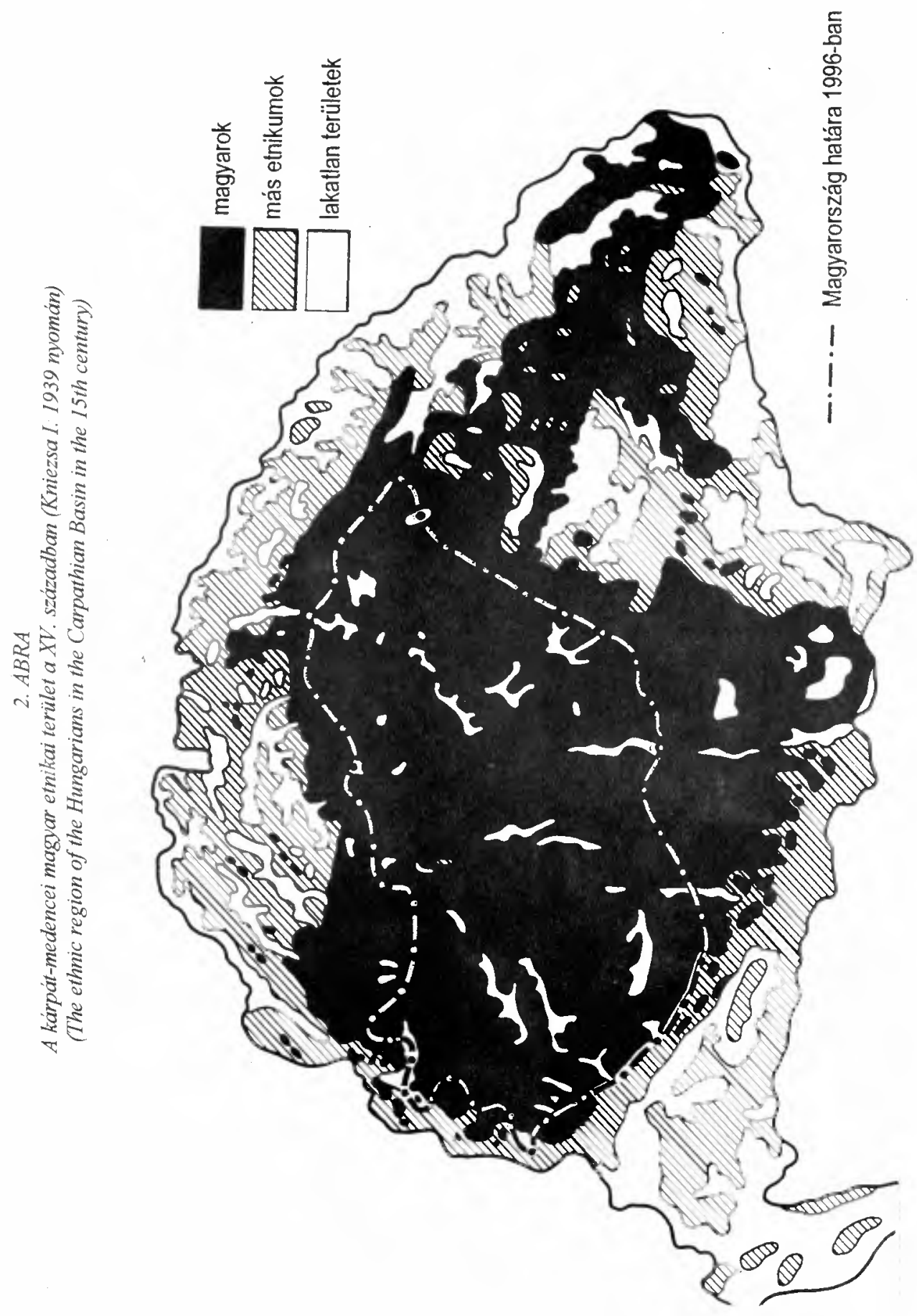


A török hódoltság másfél évszázada alatt a magyar államiság folytonosságát fenntartó Erdélyi Fejedelemségben elsösorban az 1599-1604 és 1657-1661 közötti Habsburg-román (G. Basta, M. Viteazul), illetve török-tatár hadjáratok pusztították legnagyobb mértékben az itteni magyarságot, és zilálták szét a székelyföldi, a partiumi magyar etnikai tömböket o̊sszekötő magyar településterületet. Ennek köszönhetően a XVII. század második felétől Erdélyben a magyarság már kisebbségbe került a védettebb hegyvidéki területeken élö, folytonos havasalföldi és moldvai utánpótlás miatt is egyre jobban szaporodó románokkal szemben. Az ország déli és középső részeinek földönfutóvá vált magyar lakossága ugyanakkor jelentös mértékben erősítette a Felvidék magyarságát, melynek eredményeként a német polgárság rovására a magyarok többségbe kerültek pl. Kassán, Rozsnyón, a jelenleg szinte teljesen szlováklakta Sáros vármegyében pedig a honfoglalás óta nagy tömegben élő itteni magyarok ez időszakban a lakosságnak még mindig a felét képezték. A magyarok aránytalanul nagy vesztesége annak volt köszönhetö, hogy településterületeik túlnyoııó része - háborúk idején szinte védhetetlen - sík- és dombvidéki, folyóvölgyi tájakra terjedt ki. Esetenként azonban a kedvezö, védettséget nyứjtó természeti környezet (pl. a Csallóközben, Sárközben, Kelet-Drávaszögben, a szlavóniai Vuka mocsárvidékén, Nagy-, Kis-Sárréten, Bodrogközben, nyíri lápvidéken) vagy bizonyos politikai tényezök (pl. a szultáni, hász birtoknak számító alföldi mezővárosok: Kecskemét, Nagykörös stb.) a középkori, autochton magyarság túlélését is biztosították a hadjáratok sújtotta régiókban.

\section{Majténytól Világosig (1711-1849)}

A török hódoltság másfél évszázada után, majd a Rákóczi-szabadságharc leverését követően szinte azonnal megindult a periféria-területek magyarságának az elnéptelenedett, de mezőgazdasági szempontból rendkívül termékeny alföldi területekre (pl. Kiskunság, Jászság, Nagykunság, Csongrâd) való, többnyire feltartóztathatatlan jobbágyszökésekben megnyilvánuló elvándorlása. Ennek a hatalmas méretü, etnikaiterületi koncentrációval járó, az alföldi-đunántúli magyar etnikai tömbök "újjáéledését" biztosító belső magyar migrációnak a jelentősége csak a IX. század végi honfoglaláshoz és a tatárjárás utáni újranépesüléshez volt fogható. A háborúk idején nagyobb védelmet nyújtó, túlnépesedett, északi és keleti hegyvidékröl szlovákok, ruszinok és románok ezrei yándoroltak a belső alföldi területekre leköltözött magyarok helyére, illetve szétszórtan a magyar etnikai terület belsejébe (Szabó I. 1941). A XVIII. század során a Kárpát-medence egyes részein (pl. Bácska, Bánság, Kelet-Szlavónia, DK-Dunántúl) élő népesség hallatlanul tarka etnikai-vallási összetételének kialakulásában a népességkiegyenlítést §zolgáló, és a müvelésbe vonható termőföld térbeli eloszlását követö önkéntes vándorlás mellett kiemelt szerepet játszottak a különböző szervezett telepítések. A Habsburgok gazdasági, vallási, etnikai szempontokat mérlegelö telepitö-kolonizációs politikája leginkább a katolikus vallású és német etnikumú lakosság betelepitését támogatta, míg a protestánsok és a magyarok visszatelepülését - különösen a Délvidéken - évtizedekig megakadályozta. Söt az ellenreformáció során pl. a Felvidék ÉNY-i részén a református magyar lakosság elüldözése és helyükre római katolikus szlovákok letelepítése a magyar etnikai terület további zsugorodását eredményezte (Csapodi Cs. 1943).

A XVIII. századi nagy vándormozgalmak eredményeként 1720 és 1790 között a Kárpátmedence össznépessége 4,3 millióról 9,9 millióra, a magyarok száma 1,7-ről 3,1-re, a nem-magyaroké pedig - föként a több mint 3 millió német, szerb, román, ruszin stb. bevándorlónak köszönhetően-2,6-ról 6,8 millióra növekedett (Wellmann I. 1989, Kovács 
A. 1920., Szabó I. 1941) (3. ábra). Ezzel a magyarok és a nemzetiségek között alapvetö arányeltolódás következett be. Az államalkotó nemzet, a magyarok aránya a XVIII. század végére, a felvilágosodás folyamatába ágyazott nacionalizmus megszületésének pillanatában - honfoglalásuk óta - még soha nem látott alacsony szintre $(31,5 \%)$ süllyedt (1500: $80 \%, 1720: 40,7 \%)$. Tetemesen összezsugorodott etnikai területük pedig egy számtalan idegen nyelvszigettel és lakatlan területfolttal tarkított - nagy és egy kisebb (székelyföldi) etnikai tömbre szakadt (4. ábra).

A XVI-XVII. század pusztításai és az azt követö XVIII. századi, több milliónyi lakost érintő migrációk a vizsgált terület magyar demográfiai dominancián nyugvó középkori etnikai térszerkezetét végérvényesen átformálták, kialakítva a mai etnikai területek körvonalait. A falusi térségekben a lassan stabilizálódó magyar etnikai (nyelv) határ a XVIII. század vége óta nem módosult számottevően.

$\mathrm{Az}$ újkori népvándorlások, telepítési akciók lecsillapodását követően, a XIX. század során a Kárpát-medence legkedvezőbb mezőgazdasági termelési adottságú, éppen ezért nagyobb fokú népességeltartó képességü, központi fekvésú területein lakó magyarság lélekszáma és aránya a nemzetiségekhez képest háromszoros mértékben növekedett. A magyarok száma (és aránya) az 1790-re becsült 3,1 millióról (31,5\%-ról) az 1848-as forradalom előestéjén Fényes E. (1842) szerint 4,8 millióra (37,4\%-ra) nőhetett. Ezt az ígéretes magyar etnikai gyarapodást a század derekán csupán a szabadságharc súlyos elsősorban délvidéki és erdélyi - veszteségei tartóztatták fel rövid időre.

\section{Világostól Trianonig (1849-1920)}

A levert szabadságharcot követö 1850-es osztrák népszámlálás szerint a magyarok lélekszáma a súlyos háborús veszteség miatt az 1840-es állapothoz (4,8 millió) képest alig változott. Az osztrák-magyar kiegyezést (1867) követően azonban a magyar anyanyelvúek száma (és aránya) 1880-ban 6,4 millióra (41,2\%-ra) nőtt, 1910-ben pe dig már meghaladta a 10 milliót $(48,1 \%$-ot) (1. táblázat). A magyarok nagyarányú etnikai gyarapodása természetesen nem az erószakos magyarosítás számlájára volt írható, hiszen erre az osztrák-magyar kiegyezésig (1867) a legcsekélyebb lehetöség sem volt. A magyarok számára kedvező, az I. világháborúig tartó etnikai átrétegződés, arányeltolódás föként a magyarok nagyobb természetes szaporodásának, a kedvezötlen mezögazdasági adottságú, hegyvidéki peremterületek nemzetiségi lakosait a központi fekvésủ magyar nyelvterületen szétszóró belsỏ vándorlásoknak, a magyar nyelvi környezetben lezajló természetes beolvadásnak és a magyaroknak a nemzetiségekhez képest kisebb mértékü kivándorlásának volt jórészt köszönhetỏ (Kovács A. 1920, 1925, Katus L. 1988). Az elmagyarosodást, a feltünỏ magyar etnikai térfoglalást a magyar nemzetnek és nyelvnek 1867 utáni kitüntetett szerepe/helyzete is segítette. Ugyanakkor meg kell említenünk, hogy az ipari és városi nemzetiségek ezreinek nyelvváltása, elmagyarosodása jelentös részben arra volt visszavezethetö, hogy a magyar mezögazdasági keresökön belül a földnélküliek, agrárproletárok aránya $(1910=47 \%)$ messze meghaladta a nemzetisége-két (ruszinok: 23,6\%, németek: 27,3\%, románok: 31,3\%, szlovákok: 33,3\% stb.) (Kovács $A$. 1920). Ennek következtében a századforduló táján, a nagyfokú iparosítás, gazdasági fellendülés idején ezek a nincstelen magyar falusi tömegek a nemzetiségekhez képest jóval nagyobb mértékben települtek le a nem magyar jellegü, vagy vegyes etnikumú városokban, ahol ök is hozzájárultak ahhoz, hogy viszonylag rövid idö alatt a magyar lett a helybeli népesség túlnyomó részének az anyanyelve. 


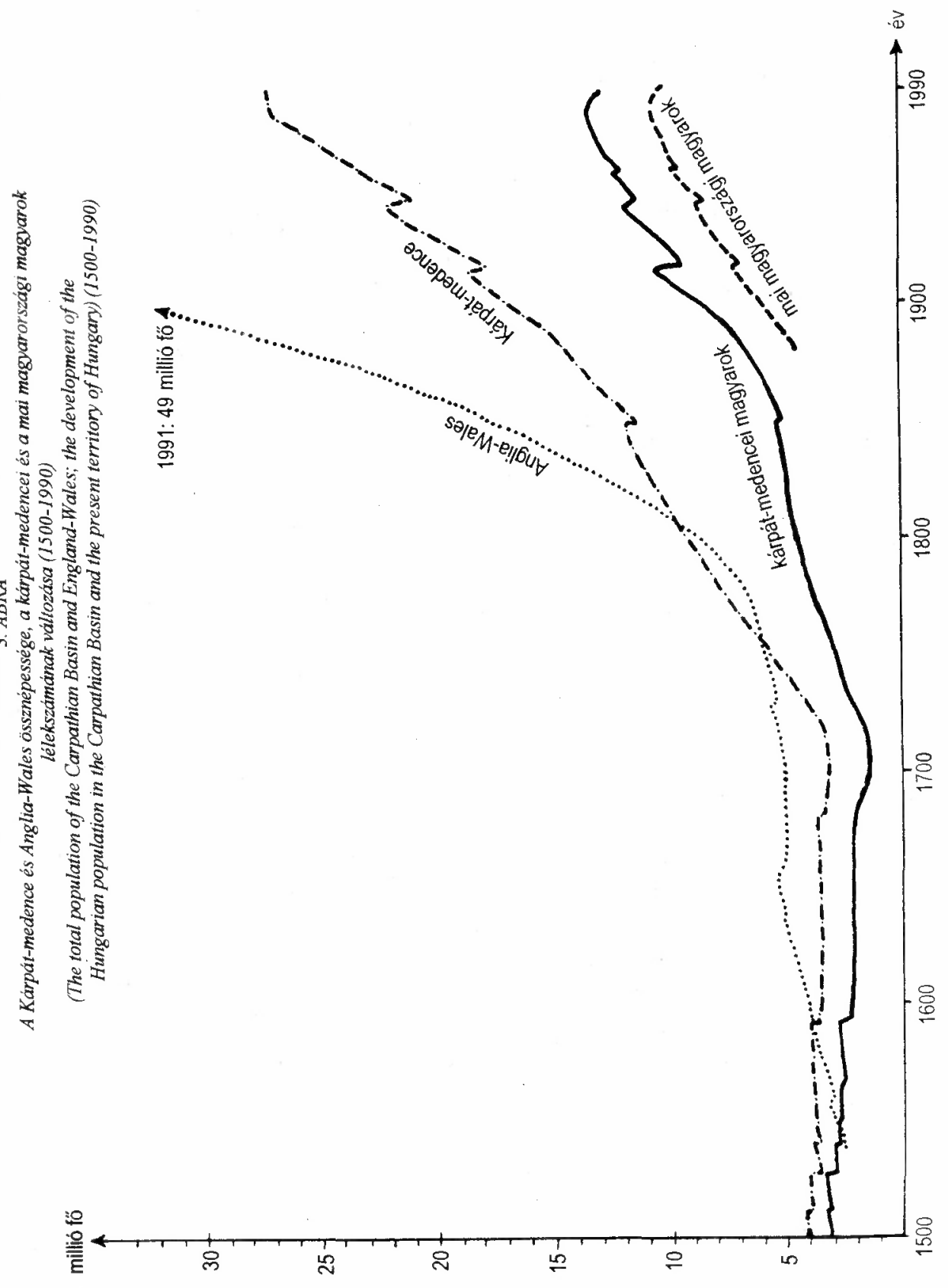




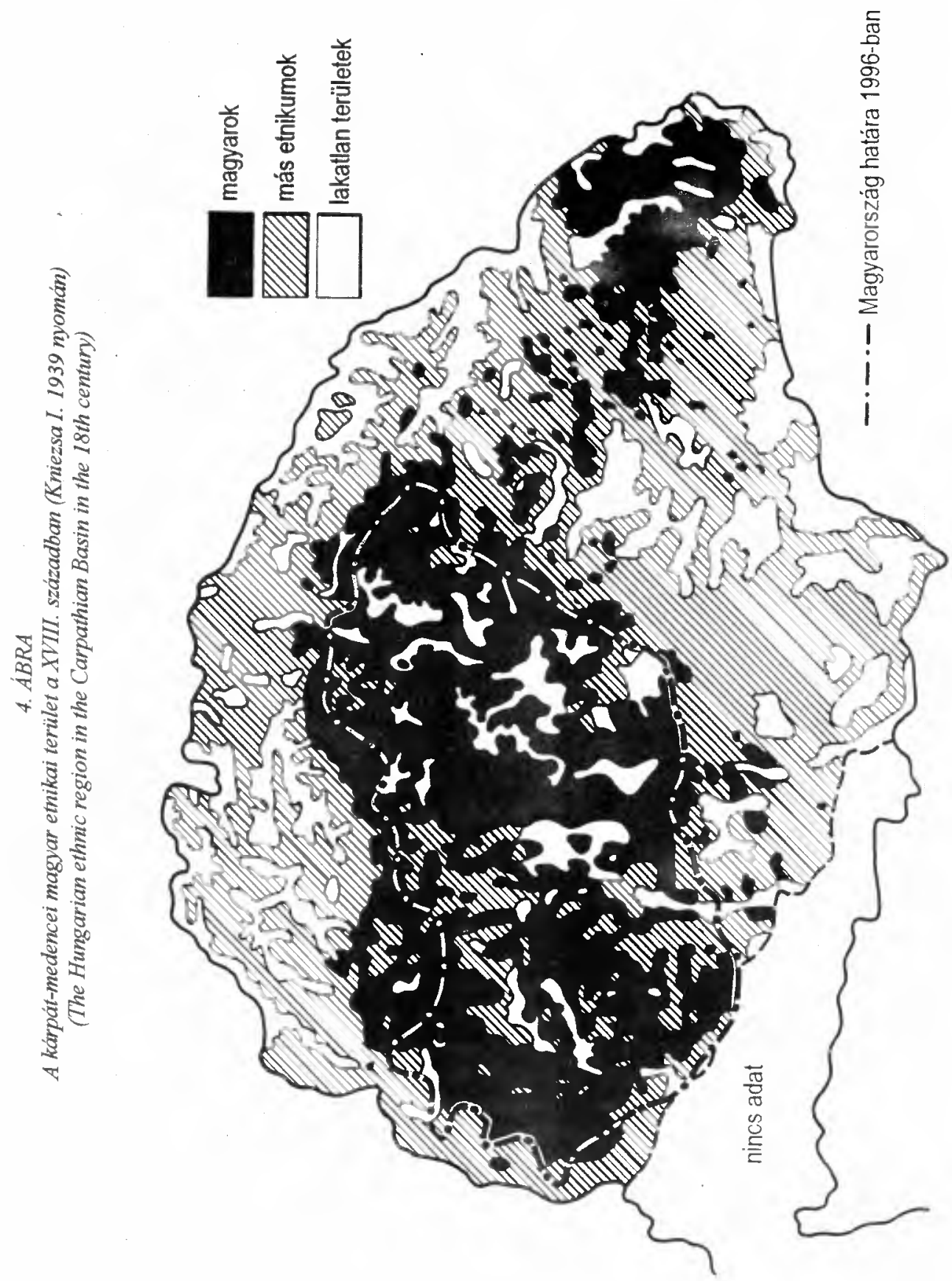




\section{TÁBLÁZAT}

A magyarok számának változása a Kárpát-medence egyes területein 1880-1990 között a népszámlálások adatai szerint

(The changes in the number of Hungarian population in the individual regions of the Carpathian Basin between 1880-1990, according to data of censuses)

\begin{tabular}{|c|c|c|c|c|c|c|}
\hline év & \multicolumn{2}{|c|}{$\begin{array}{l}\text { Kárpát-medence (a történeti } \\
\text { Magyarország) területe }\end{array}$} & \multicolumn{2}{|c|}{$\begin{array}{c}\text { Mai Magyarország } \\
\text { területe }\end{array}$} & \multicolumn{2}{|c|}{$\begin{array}{c}\text { Magyarország mai } \\
\text { területén kívül a Kárpát- } \\
\text { medencében }\end{array}$} \\
\hline 1880 & 6419146 & $100,0 \%$ & 4354613 & $67,8 \%$ & 2064533 & $32,2 \%$ \\
\hline 1910 & 10047605 & $100,0 \%$ & 6730299 & $67,0 \%$ & 3317306 & $33,0 \%$ \\
\hline 1030 & 10650737 & $100,0 \%$ & 8000335 & $75,1 \%$ & 2650402 & $24,9 \%$ \\
\hline 1941 & 11912284 & $100,0 \%$ & 8655798 & $72,7 \%$ & 3256486 & $27,3 \%$ \\
\hline 1949 & 11547626 & $100,0 \%$ & 9076041 & $78,6 \%$ & 2471585 & $21,4 \%$ \\
\hline 1960 & 12567714 & $100,0 \%$ & 9786038 & $77,9 \%$ & 2781676 & $22,1 \%$ \\
\hline 1970 & 12969985 & $100,0 \%$ & 10166237 & $78,4 \%$ & 2803748 & $21,6 \%$ \\
\hline 1980 & 13412752 & $100,0 \%$ & 10579898 & $78,9 \%$ & 2832854 & $21,1 \%$ \\
\hline 1990 & 12929048 & $100,0 \%$ & 10225529 & $79,1 \%$ & 2703519 & $20,9 \%$ \\
\hline
\end{tabular}

\begin{tabular}{|c|c|c|c|c|c|c|c|}
\hline év & Szlovákia & Kárpátalja & Erdély & Vajdaság & Horvátország & Muravidék & $\begin{array}{c}\text { Órvidék } \\
\text { Burgenland }\end{array}$ \\
\hline 1880 & 574862 & 105343 & 1045098 & 265287 & 49560 & 13221 & 11162 \\
\hline 1910 & 881320 & 185433 & 1658045 & 425672 & 119874 & 20737 & 26225 \\
\hline 1930 & 585434 & 116548 & 1480712 & 376176 & 66040 & 15050 & 10442 \\
\hline 1941 & 761434 & 233840 & 1711851 & 465920 & 64431 & 16510 & 2500 \\
\hline 1949 & 354532 & 139700 & 1481903 & 428554 & 51399 & 10246 & 5251 \\
\hline 1960 & 518782 & 146247 & 1616199 & 442560 & 42347 & 9899 & 5642 \\
\hline 1970 & 552006 & 151949 & 1625702 & 423866 & 35488 & 9064 & 5673 \\
\hline 1980 & 559801 & 158446 & 1691048 & 385356 & 25439 & 8617 & 4147 \\
\hline 1990 & 567296 & 155711 & 1604266 & 339491 & 22355 & 7637 & 6763. \\
\hline
\end{tabular}

Forrás: 1880-1990. évi magyar (anyanyelv), 1930., 1941., 1950., 1961., 1970., 1980., 1991. évi. csehszlovák, szlovák (nemzetiség), 1950., 1959., 1970., 1979., 1989. évi szovjet (nemzetiség), 1930, 1941., 1948., 1956., 1966. (anyanyelv), 1977., 1992. évi román (nemzetiség), 1931. (anyanyelv), 1948., 1961., 1971., 1981., 1991. évi jugoszláv (nemzetiség), 1934. (anyanyelv), 1951., 1961., 1971., 1981.. 1991. évi osztrák (környezeti nyelv) népszámlálások eredményei.

A városi népesség nagy ütemü elmagyarosodása eredményeként 1910-ben az ország városi lakosságának már 77,5\%-a magyarnak számított és $88,9 \%$-a tudott magyarul. Erre az etnikai folyamatra a legjobb példát a fôváros, Budapest szolgáltatta, ahol a magát magyar anyanyelvúeknek vallók aránya 1880 és 1910 között 56,8-ról 85,9\%-ra növekedett. A magyarságot erősítő nyelv és identitásváltás, önkéntes és szívesen vállalt elmagyarosodás jórészt a társadalom felsőbb rétegeit érintette. Az ország 300.706 fös értelmiségének $82,3 \%$-a vallotta magát magyarnak, 8,6\%-a németnek, 4,3\%-a románnak, 1,5\%-a szlováknak (Kovács A. 1925). Főként az egyre jobban elmagyarosodott zsidóságnak köszönhetően a gazdasági értelmiség körében a magyarok aránya még ennél is magasabb volt $(84,5 \%)$. Természetesen ez a számunkra kedvezó etnikai folyamat nem egyformán érintette a nemzetiségeket. Az 1848/49-es szabadságharc és az I. világháború közöłt elmagyarosodott kb. 2 millió lakosnak több mint harmada a zsidók, negyede a németek és ötöde a szlovákok közül került ki (Katus L. 1988). Az Osztrák-Magyar 
Monarchia utolsó évtizedeiben a nemzetiségeknek a magyarokkal szemben - az élet szinte minden területén tapasztalt, értelmiségi rétegeik által rendkívüli módon sérelmezett háttérbe szorulása, etnikai térvesztése az I. világháború után a gyökeresen megváltozott politikai helyzetben a csehek (szlovákok), románok, szerbek magyarellenes, revansjellegü hadjárataiban fontos hivatkozási alapot jelentett.

$\mathrm{Az}$ említett folyamatok ellenére a magyar etnikai terület jelentékenyebb elöretörése a rurális térségekben csupán a nyelvhatárok egyes szakaszain élt, aktív két (vagy több)nyelvü, rendkivuull bizonytalan etnikai identitású népesség lakta területeken (NyitraBars-Hont, ÉK-Abaúj, Közép-Zemplén, Kelet-Ugocsa, Közép-Szatmár stb.) és a magyar etnikai tömbökön belül lévő kis, szétszórt - föként szlovák és német - nyelvszigeteken volt megfigyelhetö. $\mathrm{Az}$ etnikai-területi kiterjedést tekintve kisebb, de demográfiaitársadalmi fontosságát tekintve sokkal nagyobb jelentőségü volt az államhatalọn központjainak, a városoknak a rohamos elmagyarosodása. Ennek eredményeként a magyar etnikai terület és a nyelvhatárok-vásárvonalak városainak túlnyomó része szinte homogénnek, de legalábbis 80-90\%-ban magyarnak mutatkozott, de a nemzetiségi területek számos városa is magyar nyelvszigetté vált az 1910-es anyanyelvi térképen (Zólyom, Nagyrőce, Nagymihály, Varannó, Munkács, Szamosújvár, Abrudbánya, Déva, Vajdahunyad stb.).

\section{Trianontól Bécsig (1920-1938)}

Az I. világháborút követően, a trianoni békeszerzödésben a gyöztes antant hatalmak cseh, román és szerb szövetségeseik szinte legvérmesebb területi követeléseit is kielégítve Magyarország területét alapvetően öt, szintén többnemzetiségú állam között osztották fel. A gyökeres hatalomváltást követỏen, mely a korábbi magyar államterület 2/3-ának, a magyar anyanyelvủek 1/3-ának elcsatolásával járt, 1918 és 1924 között 350 ezer magyar menekült költözött át - 197 ezren Erdélyböl, 107 ezren a Felvidékröl, 45 ezren a Délvidékrổ - a trianoni Magyarországra (Rónai A. 1938). Ettól az időszaktól kezdve a trianoni határokon innen és túl élö magyarok népesedési helyzete, etnikai területük sorsa végérvényesen elvált egymástól. Az Osztrák-Magyar Monarchia utódállamaiban eluralkodott kisebbségellenes légkör, a megváltozott népszámlálási módszerek (pl. cigányok, zsidók külön nemzetiségi kategóriába sorolása), az asszimiláció és a már említett, több százezer magyart érintỏ kényszermigrációk miatt a határainkon túl élő kárpát-medencei magyarok száma 1910-1930 között 3,3 millióról 2,6-ra csökkent. A magyar kisebbség etnikai területe 1910-hez képest a fenti okok következtében a Felvidéken és Kárpátalján föként a nyelvhatár városaiban, Nyitra-Léva-Komárom között, Kassa és Töketerebes vidékén, Ugocsában, a Romániához csatolt területek közül elsősorban Szatmárban, valamint a jelentős zsidó és német eredetủ polgárság lakta városokban (pl. Nagyvárad, Szatmárnémeti, Nagykároly, Nagybánya, Kolozsvár), a Délvidéken pedig a határvidéki Szabadkán, Zomborban zsugorodott össze. Ugyanakkor a trianoni magyar államterületen a természetes asszimiláció, áttelepülések, repatriálások és a kisebbségekre nehezedỏ nyomás miatt felgyorsult magyarosodás következtében a magyar anyanyelvüek száma 6,7-rỏl 8 millióra, aránya 88,4\%-ról 92,1\%-ra nött. Hasonló mértékủ volt az elmagyarosodás a magyar föváros, Budapest területén is (1910: 85,9\%, 1930: $93,9 \%$ magyar) (Kocsis K. 1994). A román és szlovák kisebbség közel felénekharmadának nyelvváltása miatt tucatnyi szlovák és néhány román. folt tünt el Magyarország 1930-as anyanyelvi térképén. 


\section{Bécstöl a frontátvonulásig (1938-1944/45)}

A két világháború kỏzötti időszakban a kárpát-medencei, kb. 3 milliónyi magyar kisebbség számának gyors (részben csak statisztikai) fogyását az 1938-1941 közötti terileti revíziók (pl. 1., 2. bécsi döntés) tartóztatták fel, melynek során a magyar kisebbség nagy részét tömöritő területeket (mai Dél-Szlovákia, Kárpátalja, Észak-Erdély, Bácska, mai horvát Baranya, szlovéniai Muravidék) a fasiszta tengelyhatalmak - elsỏsorban taktikai megfontolásból, de túlnyomórészt etnikai szempontok alapján - visszacsatolták Magyarországhoz (Rónai A. 1989). A visszacsatolt területeken a volt magyarországi közalkalmazottak (hivatalnokok, rendőrök, katonák stb.) megjelenésével, a bukovinai magyarok betelepítésével, a kétnyelvü, bizonytalan identitású népesség és a zsidók többségének ismét magyarrá válásával 1930-hoz képest 600 ezer fóvel gyarapodott a magukat magyar anyanyelvűnek vallók száma, különösen Kárpátalján, a Felvidéken és a Délvidéken (1. táblázat). A magyar nyelvhatár az 1941-es népszámlálás eredményei szerint rendkívüli módon közelített az 1910-es állapothoz. Jelentősebb eltérés csupán a román fennhatóság alatt maradt Dél-Erdélyben mutatkozott, ahol 100 ezer magyar clüldôzése-elmenekülése következtében elsősorban Brassó, Temesvár, Torda, Arad, Petrozsény, Nagyenyed városok és a Küküllö-Maros-vidék magyarsága szenvedett súlyos veszteségeket. Eme világháborús népszámlálási időpontban a revíziós sikereken fellelkesült ország központi, trianoni teruletén a népesség magyarosodása és a nem magyar etnikai szigetek-szórványok felszívódása a korábbi nagy lendülettel folytatódott (magyar anyanyelvứek: 92,9\%, magyar nemzetiségủek: 95,7\%).

A magyarság számára rendkívül kedvező etnikai-demográfiai állapot azonban csak az ország német megszállásáig (1944. március 19.) tartott. Ezt követően német követelésre a magyar belügyi apparátus megkezdte az izraelita vallású lakosság (1941: 725 ezer fö) ossszegyüjtését, majd Németországba való deportálását. Ez az intézkedés a közel 600 ezernyi magyar anyanyelvủ és identitású izraelita eltávolításával rendkívül súlyos yeszteséget jelentett különösen a kárpátaljai és az észak-erdélyi magyarok számára. A magyar zsidók öncsonkítás jellegü deportálása a legnagyobb arányú magyar etnikai yeszteséget - a trianoni határokon túli területek közül - a kárpátaljai és az észak-erdélyi yárosokban (pl. Beregszász, Munkács, Ungvár, Nagyszőlős illetve Nagyvárad, Kolozsvár, Szatmárnémeti, Máramarossziget, Marosvásárhely, Nagybánya) eredményezett, megteremtve ezzel is az ukránok, az oroszok és a románok frontátvonulást követő tömeges betelepitésének fizikai feltételeit.

\section{4-tól napjainkig}

A II. világháború utolsó hónapjaiban megindult, a 40-es évek végéig folytatódott kényszermigrációk, államilag szervezett, etnikai és agrárszociális célzatú telepítések kỏvetkeztében több millióan változtatták meg lakóhelyüket. Részben a magyar hadsereg nyomában, részben a deportálások eredményeként tỏbb mint 300 ezer magyarnak kellett elhagynia a magyar állam számára ismét elveszett felvidéki (120.500), kárpátaljai (25.000), erdélyi (125.000) és délvidéki (45.500) területeket, akiknek a helyére a szomszédos államok nagyarányú telepitési akcioinak keretén belül szlovákok, ukránok, oroszok, románok és szerbek százezrei költooztek. Ezen nemzetpolitikai és szociális jellegũ - csehszlovák, szovjet, román, jugoszláv - telepítések fơ céljának a határvidéki 
kulcsfontosságú városok (pl. Galánta, Érsekújvár, Léva, Rozsnyó, Kassa, Ungvár, Szatmárnémeti, Kolozsvár, Nagyvárad, Arad), területek addigi magyar jellegének megszüntetését és ezáltal a jövőbeli esetleges magyar revíziós igények lehetetlenné tételét tekintették. Ezekben a volt kisantant országokban a szinte kizárólag a magyarok rovására elért jelentős nemzeti homogenizációs sikerek már a háború utáni első népszámlálási statisztikákban is tükröződtek. Az ellenségesnek, a magyar revansizmus ötödik hadoszlopának tekintett kárpát-medencei magyar kisebbségek lélekszáma a deportálások és a szélsőségesen magyarellenes légkör hatására az 1941-beli 3,2 millióról 1949-ben 2,4 millióra csökkent a bevalláson alapuló népszámlálási statisztikák szerint (1. táblázat).

A térség országaihoz hasonlóan az ismét 93 ezer $\mathrm{km}^{2}$ területüre zsugorodott Magyarországon is hasonló etnikai homogenizáció felé mutató folyamatok zajlottak le. 1945-1950 között közel 220 ezer német deportálására, 73 ezer szlovák önkéntes kitelepülésére és kb. 320 ezer magyar menekült betelepülésére került sor. Ezen migrációk és a kisebbségek identitására katasztrofális hatást mérö egyéb események (deportálások, értelmiség java részének távozása, etnika területük teljes szétforgácsolódása, magyar környezetben való felolvadása stb.) következtében a mai Magyarország területén élt kisebbségek száma 660 ezerről 129 ezerre csökkent 1941-1949 között, ami a magát magyarnak valló népesség számának és arányának 9,1 millióra, illetve 98,6\%-ra való növekedését eredményezte.

$\mathrm{Az}$ azóta eltelt több mint négy évtizedben a térség volt szocialista országaiban a társadalom, a gazdaság sżocialista típusú átszervezése (államosítás, a mezőgazdasảg erőszakos kollektivizálása, a hagyományos, jelentős cselekvési autonómiával rendelkezö paraszti társadalom, zárt etnikai (falu) közösségek felbomlasztása, szétzüllesztése, indokolatlan extenzív iparosítás stb.) hallatlanul megnövelte a népesség térbeli mobilitását és több százezernyi, korábbi paraszti tömegeket késztetett az új munkásosztály fellegváraiba, a sokszorosára duzzadt népességủ városokba. Mindez természetesen a többségi, államalkotó nemzetek városokon belüli arányát, esetleg hegemóniáját növelte. Sok esetben pedig a városiasítás az adott városban évszázadok óta lakó, nagy arányt képviselő nemzetiségek erőszakos visszaszorítását is célozta. Általánosságban elmondható, hogy az elmúlt négy évtizedben a magyarok száma mind a mai határokon belül, mind kívül az 1980-as évek elejéig egyenletesen nőtt (10,6 ill. 2,8 millióra), majd a vészesen visszaesett természetes szaporodás és a szomszédos területekről Magyarországra való növekvö áttelepülés miatt jelentősen csökkent (10,2 ill. 2,7 millióra). A magyar etnikai terület kiterjedése 1949-1990 között nem változott lényegesen, csupán a városok, a nyelvszigetek esetében volt $-\mathbf{a}$ felgyorsult belső térbeli mobilitás és asszimiláció miatt - a trianoni területen belül számottevó térhódítás, a határainkon túl pedig jelentős visszaszorulás megfigyelhetö. Századunk második felében azonban az uralkodó nemzet és a kisebbségek többé-kevésbé békés etnikai-demográfiai párharca elsősorban a falusiak százezreit felszívó városokban zajlott (zajlik) le. Különösen gyakori és extrém etnikai átalakuláson mentek keresztül a - trianoni határon kívül és belül - nyelv- és államhatár közelében fekvő városok, az 1914-1945 között lezajlott többszöri államhatalom változások, terület ide-oda csatolások, tömeges kényszermigrációk, valamint a sokszor megmagyarázhatatlanul nagy népességkon-centrációt eredményezó urbanizáció következtében.

Az 1990 körüli népszámlálások idején a Kárpát-medence 30,5 milliós népességének már csak 42,1\%-a (12,9 millió fö) vallotta magát magyar nemzetiségünek (1. táblázat). A népszámlálási adatok szerint a mai Magyarországot szinte tökéletesen kitöltỏ magyar etnikai területet már csak 20 település apró, szétszórt színfoltja tarkítja (Kocsis K. 1995). 
Ugyanakkor a határainkon túli, 2,7 milliónyi kárpát-medencei magyar etnikai területe számos esetben még meg tudta órizni viszonylagos etnikai kompaktságát többnyire a mai magyar államhatár szomszédságában és a Székelyföldön. Ezek a magyar nemzeti kisebbségek jelenlegi etnikai magterületei a következők: Szlovákiában Csallóköz, Párkány, Ipolyság, Fülek, Tornalja térsége, a Gömör-Tornai karszt és a Bodrogköz; Ukrajnában a Beregszász környéki határsáv Ungvár és Nagyszőlős között; Romániában a Székely föld és a szatmár-észak-bihari határvidék; Jugoszláviában ÉK-Bácska (5. ábra).

A honfoglalás óta elmúlt 1100 év a magyar etnikai térszerkezet átalakulása alapján négy fö periódusra osztható fel. Az elsö, a X-XV. század közötti időszakot - föként a lakatlan területek és a nemzetiségek rovására történt - magyar transzgresszió; a második, a XVIXVIII. századokra vonatkozó periódust - a belsó háborúk, a török hódoltság, a felszabadító harcok és az azokat követő migrációs folyamatok eredményeként - rendkívüli magyar etnikai regresszió és azzal párhuzamos nemzetiségi transzgresszió jellemezte. A harmacik, többnyire a XIX. századra és a XX. század elejére kiterjedő időszakban természeti és társadalmi tényezőknek köszönhetö - túlnyomórészt önkéntes magyarosodás eredményeként a középkori magyar etnikai terület regenerálása felé mutató, magyar etnikai transzgresszió és nemzetiségi, főként szlovák, német regresszió bontakozott ki és gyorsult fel századunk elejére, melyet a trianoni békeszerződés, a történelmi magyar államterület felosztása tartóztatott fel. A negyedik, máig tartó időszakban a trianoni teruleten fokozódó magyar etnikai elöretörés, a trianoni határokon túl a szlovák, ruszin, román, szerb, horvát, szlovén elörenyomulással szembeni általános magyar etnikai-terủleti regresszió volt megfigyelhető, melyet csupán 1938-1944 között szakított meg a reviziós sikerek következményeként egy rövid, ideiglenes magyar etnikai térnyerés.

\section{Irodalom}

Barsy Gy. (1938) Magyarország népessége a honfoglalás óta. In: Magyar Statisztikai Szemle 4. 348-358. o.

Bodor A. (1914) Délmagyarországi telepitések története és hatása a mai közállapotokra. Stephaneum, Budapest.

Csapodi Cs. (1943) Az északnyugati magyar-tót nyelvhatár megváltozása és a katolikus restauráció. Stephaneum, Budapest.

Dányi D. (1993) Az 1850. és 1857. évi népszámlálás. Központi Statisztikai Hivatal, Budapest.

Fényes E. (1842) Magyarország statistikája. I. kötet, Pest.

Györffy Gy. (1995) A honfoglalók száma és az Árpád-kor népessége. In: Kovacsics J. (szerk.) A honfoglalás és az Árpád-kor népessége, Magyarország történeti demográfiája I., Központi Statisztikai Hivatal, Budapest, 37-41. o.

Jászi O. (1912) A nemzeti államok kialakulása és a nemzetiségi kérdés. Grill Károly Kiadóvállalat, Budapest.

Katus L. (1988) Nemzetek és népszaporulat. In: Glatz F. (szerk) Magyarok a Kárpátmedencében. Pallas Lap- és Könyvkiadó Vállalat, Budapest, 171-174. o.

Kniezsa I. (1938) Magyarország népei a XI-ik században. Budapest.

Kniezsa I. (1939) A magyarság és a nemzetiségek. In: Az ezeréves Magyarország. Pesti Hirlap Rt., Budapest, 91-114. o.

Kniezsa I. (1941) Adalékok a magyar-szlovák nyelvhatár történetéhez. Athenaeum, Budapest. 


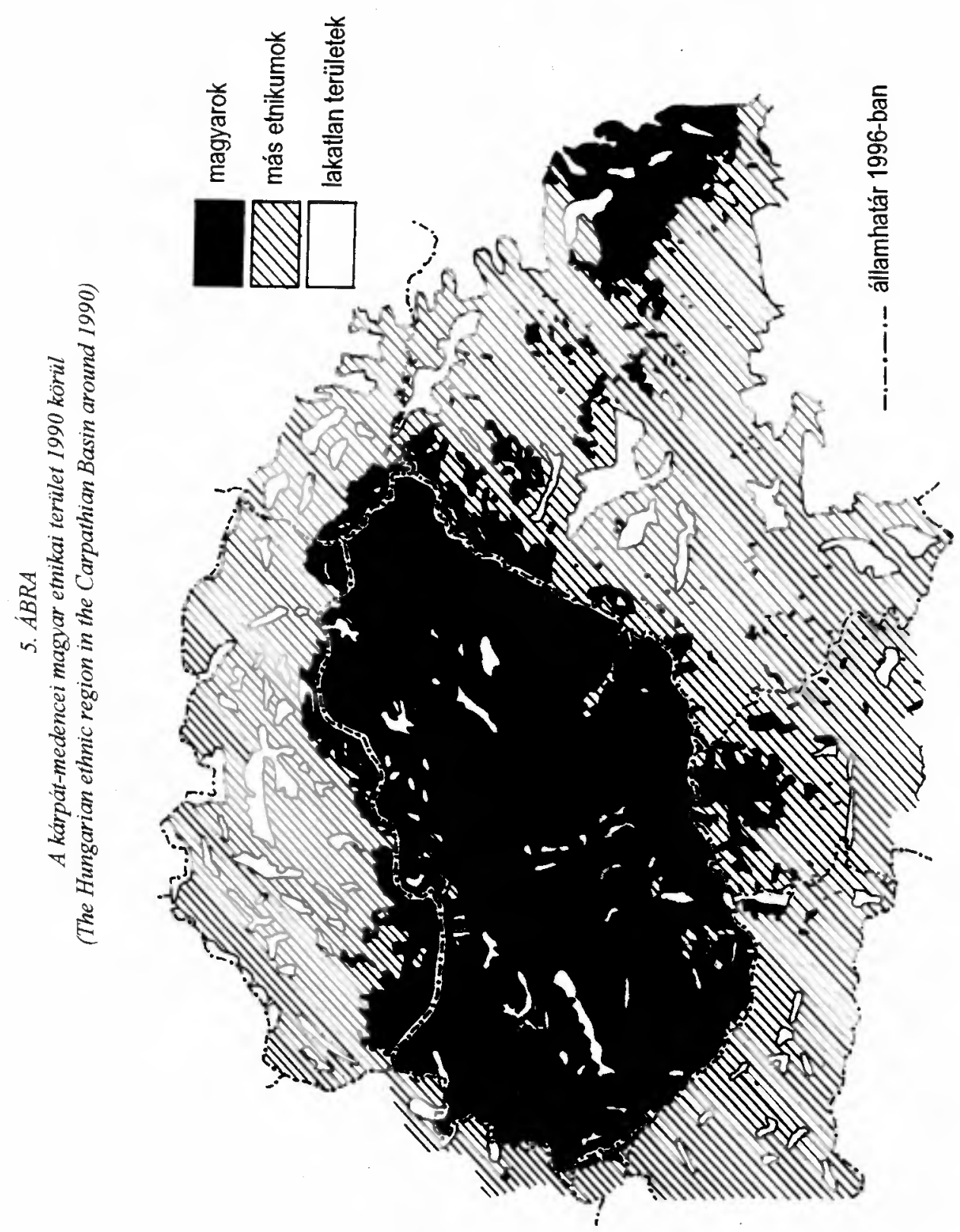


Kocsis K.-Kocsisné Hodosi E. (1991) Magyarok a határainkon túl - a Kárpátmedencében. Tankönyvkiadó, Budapest.

Kocsis K. (1994) Budapest és régiója etnikai térszerkezetének átalakulása (1850-1990). Földrajzi Értesitó XLIII. 3-4. 299-324. o.

Kocsis K. (1995) Magyarország etnikai szerkezete. In: Iskolakultúra V. 3-4. 30-39. o.

Kovács A. (1920) Magyarország népességének fejlődése a török uralom megszünte óta. A magyar béketárgyalások. Jelentés a magyar békeküldöttség mưködéséröl Neuilly $S / S$. ben 1920 január-március havában. Budapest, I. kötet, 36-46. o.

Kovács A. (1925) Nemzetiségi erőviszonyok a történeti Mảgyarországon. In: Dr. Gróf Klebelsberg Kunó Emlékkönyv. Budapest, 615-630. o.

Kovacsics J. (1995) A történeti demográfia válaszai és nyitott kérdései az Árpád-kori népesség számára vonatkozóan. In: Kovacsics J. (szerk.) A honfoglalás és az Árpád-kor népessége. Magyarország történeti demográfiája I., Központi Statisztikai Hivatal, Budapest, 3-36. 0 .

Kristó Gy. (1995) Magyarország lélekszáma az Árpád-korban. In: Kovacsics J. (szerk.) A honfoglalás és az Árpád-kor népessége. Magyarország történeti demográfiája I., Központi Statisztikai Hivatal, Budapest, 42-95. o.

Mályusz E. (é. n.) A magyarság és a nemzetiségek Mohács előtt. In: Wellmann I. (szerk.) Magyar Müvelödéstörténet, Màgyar Történelmi Társulat, Budapest.

Mendöl T. (1947) A Kárpát-medence emberföldrajza. In: Bulla B.-Mendöl T. (szerk.) A Kárpát-medence földrajza. Egyetemi Nyomda, Budapest, 72-195. o.

Rónai A. (1938) Magyarok elterjedése a Földőn. Földrajzi Közlemények LXVI. 83-104. o. Rónai A. (1989) Térképezett történelem: Magvetö, Budapest.

Szabó I. (é. n.) A nemzetiségek térnyerése és a magyarság. In: Wellmann I. (szerk.) Magyar Mĩvelödéstörténet. Magyar Történelmi Társulat, Budapest, 111-136. o.

Szabó I. (1941) A magyarság életrajza. Magyar Történelmi Társulat, Budapest.

Szűcs J. (1988) A középkori Magyarország népei. In: Glatz F. (szerk.) Magyarok a Kárpát-medencében. Pallas Lap- és Könyvkiadó Vállalat, Budapest, 32-39. o.

Wellmann I. (1989) Magyarország népességének fejlödése a 18. században. In: Ember Gy.-Heckenast G. (szerk.) Magyarország története 1686-1790. Akadémiai Kiadó, Budapest, 25-80. o.

\title{
CHANGING FACE OF THE HUNGARIAN ETHNIC TERRITORY FROM THE HUNGARIAN CONQUEST TILL TODAY
}

\author{
KÁROLY KOCSIS
}

The author acquaints us with the transitions of the Hungarian ethnic territory during the past 1100 years, divided into seven chapters according to the main milestones in Hungarian history $(1526,1711,1849,1920,1938,1945)$. The study tells us that there are hardly any nations in Europe the population and ethnic territory of which changed during the past centuries as strikingly as those of the Hungarians. Perhaps it is only the Croatians - fragmented in the conflict zone of the front line between the Christians and Muslims in the 15th-17th centuries - and the Polish suffering in the German-Russian conflict zone who had a situation similar to the Hungarian one, if we look at the development of their 
ethnic territory and its frequent expansions and contractions. The rhapsodic changes of the ethnic spatial structure of Hungary were after all connected to the geographical location of the Carpathian Basin, that, in the meeting point of Western and Eastern Christianity and the Islamic world (15th-19th centuries) and that of the German and Slavic ethnic blocks, had a basic influence on historical events. Also, with its natural geographical endowments, in connection with the lifestyle of the Hungarian nation, it determined the size of the ethnic territory of the Hungarians and the limits of growth in the Medieval Ages. 